\title{
Development and evaluation of a new multi-metal binding biosorbent
}

\author{
A. Abdolali ${ }^{a}$, H.H. Ngo ${ }^{\text {a,* }}$, W.S. Guo ${ }^{\text {a }}$, D.J. Lee ${ }^{\mathrm{b}}$, K.L. Tung ${ }^{\mathrm{b}}$, X.C. Wang ${ }^{\mathrm{c}}$ \\ ${ }^{a}$ Centre for Technology in Water and Wastewater, School of Civil and Environmental Engineering, University of Technology Sydney, Broadway, NSW 2007, Australia \\ ${ }^{\mathrm{b}}$ Department of Chemical Engineering, National Taiwan University, Taipei 10617, Taiwan \\ ${ }^{\mathrm{c}}$ Key Lab of Northwest Water Resources, Environment and Ecology, Ministry of Education, Xi'an University of Architecture and Technology, Xi'an 710055, China
}

\section{H I G H L I G H T S}

- The effectiveness of a novel multi-metal binding biosorbent was studied.

- The biosorption of $\mathrm{Cd}^{2+}, \mathrm{Cu}^{2+}, \mathrm{Pb}^{2+}$ and $\mathrm{Zn}^{2+}$ on MMBBs was investigated.

- Equilibrium data were presented and the best fitting models were introduced.

- The pseudo-second order model best describe the biosorption kinetics.

- The obtained results recommend this MMBB as potentially low-cost biosorbent.

\section{A R T I C L E I N F O}

\section{Article history:}

Available online 19 December 2013

\section{Keywords:}

Agro industrial waste

Biosorption

Heavy metal

Isotherm

Kinetic study

\begin{abstract}
A B S T R A C T
A novel multi-metal binding biosorbent (MMBB) was developed by combining a group of three from the selective natural lignocellulosic agro-industrial wastes for effectively eliminating lead, cadmium, copper and zinc from aqueous solutions. Four MMBBs with different combinations (MMBB1: tea waste, corncob, sugarcane bagasse; MMBB2: tea waste, corncob and sawdust; MMBB3: tea waste, corncob and apple peel; MMBB4: tea waste, corncob and grape stalk) were evaluated. FTIR analysis for characterizing the MMBB2 explored that the MMBB2 contains more functional groups available for multi-metals binding. Comparing among the MMBBs as well as the single group biosorbents, MMBB2 was the best biosorbent with the maximum biosorption capacities of $41.48,39.48,94.00$ and $27.23 \mathrm{mg} / \mathrm{g}$ for $\mathrm{Cd}(\mathrm{II}), \mathrm{Cu}(\mathrm{II}), \mathrm{Pb}(\mathrm{II})$ and $\mathrm{Zn}(\mathrm{II})$, respectively. After 5 times of desorption with $\mathrm{CaCl}_{2}, \mathrm{CH}_{3} \mathrm{COOH}$ and $\mathrm{NaCl}$ as eluent, the MMBB2 still remained excellent biosorptive capacity, so as it could be well regenerated for reuse and possible recovery of metals.
\end{abstract}

(ㄷ) 2013 Elsevier Ltd. All rights reserved.

\section{Introduction}

Typical heavy metals such as lead, cadmium, copper and zinc in water and wastewater cause severe disasters in environment and subsequently serious types of acute and chronic diseases in human. The common techniques used for metal removal from water and wastewater includes chemical precipitation, membrane, filtration, ion exchange, carbon adsorption and co-precipitation/adsorption which involve high capital and operational costs and may have secondary wastes after processes (Bilal et al., 2013; Bulut and Tez, 2007).

In recent years, biosorption has been considered as cost effective alternatives for removing metals (Bulut and Tez, 2007; Gupta et al., 2009; Gadd, 2009a; Gadd, 2009b; Volesky, 2007). Generally,

\footnotetext{
* Corresponding author. Address: School of Civil and Environmental Engineering, University of Technology, Sydney (UTS), PO Box 123, Broadway, NSW 2007, Australia. Tel.: +61 29514 2745/1693; fax: +61295142633.

E-mail address: h.ngo@uts.edu.au (H.H. Ngo).
}

biosorption process can reduce capital costs by $20 \%$, operational costs by $36 \%$ and total treatment costs by $28 \%$ compared with the conventional systems (Loukidou et al., 2004). Thus, the interest in utilization of cheap alternatives has been significantly increased. Many attempts have therefore been made by many researchers on feasibility of biosorption potential of lignocellulosic materials as economic and eco-friendly options, both natural substances and agro-industrial wastes and by-products. These adsorbents may be classified either on basis of their availability (natural materials and industrial/agro-industrial/domestic wastes or by-products and synthesized ones) or depending on their nature (organic and inorganic materials) (Gupta et al., 2009). Among inexpensive biosorbents, most of the studies have been engrossed in lignocellulosic wastes (as naturally intact or chemically modified) such as sawdust, weed and wood waste (Asadi et al., 2008; Bulut and Tez, 2007; Pereira et al., 2010), sugarcane bagasse (Homagai et al., 2010; Martín-Lara et al., 2010; Pereira et al., 2010), fruit rind, pulp and seeds (Feng et al., 2011; Liu et al., 2012; Martín-Lara et al., 2010; Torab-Mostaedi et al., 2013), wheat or barley straw (Pehlivan et al., 2012), rice husk, hull and straw (Asadi et al., 
2008; Kazemipour et al., 2008), olive pomace and stone (Blázquez et al., 2009; Martín-Lara et al., 2012), etc. The heavy metal biorecovery can be affected by physico-chemical parameters of the solution such as $\mathrm{pH}$, ion strength, initial metal concentration, temperature and by other characteristics of the adsorbent like concentration, presence of organic and inorganic functional groups and chemical modification (Gupta et al., 2009; Montazer-Rahmati et al., 2011; Pehlivan et al., 2012; Tan and Xiao, 2009; Tan et al., 2010; Velazquez-Jimenez et al., 2013).

The present work is a preliminary study on developing a new multi-metal binding biosorbent (MMBB) by combining a group of high biosorptive capability natural lignocellulosic agro-industrial wastes (e.g., tea waste, corncob, sugarcane bagasse, grape stalk, sawdust, apple peel) to remove cadmium, copper, lead and zinc ions from aqueous solution. These wastes were selected because of the good results reported in other literatures for heavy metal removal. Besides, tea waste, sugarcane, sawdust, apple peel and grape stalk are properly available in Australia and also all over the world.

The effect of $\mathrm{pH}$, contact time, biosorbent dosage and also elution efficiency (sorption and adsorptions cycles) on adsorption capacity were then studied. Finally, the appropriate isotherm and kinetic models were established.

\section{Methods}

\subsection{Preparation of adsorbents and heavy-metal-containing effluent}

The stock solution containing $\mathrm{Cd}, \mathrm{Cu}, \mathrm{Pb}$ and $\mathrm{Zn}$ were prepared by dissolving cadmium, copper, lead and zinc nitrate salt, $\mathrm{Cd}\left(\mathrm{NO}_{3}\right)_{2} \cdot 4 \mathrm{H}_{2} \mathrm{O}, \mathrm{Cu}_{3}(\mathrm{NO})_{2} \cdot 3 \mathrm{H}_{2} \mathrm{O}, \mathrm{Pb}\left(\mathrm{NO}_{3}\right)_{2}$ and $\mathrm{Zn}\left(\mathrm{NO}_{3}\right)_{2} \cdot 6 \mathrm{H}_{2} \mathrm{O}$ in Milli-Q water. All the reagents used for analysis were of analytical reagent grade from Scharlau (Spain) and Chem-Supply Pty Ltd. (Australia). For remove any inaccuracies in metal concentration, all stock solutions were analyzed by AAS (Contra ${ }^{\circledR}$ AA 300, Analytikjena, Germany) to correct their concentration to use in experiments with required amounts.

All biosorbent were bought or collected from local market in Sydney area and after using the useful parts were washed by tap water and distilled water to remove any dirt, color or any impurity and then dried in oven (Labec Laboratory Equipment Pty Ltd., Australia) at $105{ }^{\circ} \mathrm{C}$ over night. Having ground and sieved (RETSCH AS-200, Germany) to a particle size of $75-150 \mu \mathrm{m}$, the natural biosorbents were kept in desiccator prior to use.

\subsection{Biosorption studies in batch system}

The tests were performed with synthetic multi-metal solution with concentration of $3000 \mathrm{mg} / \mathrm{L}$ for each metal by dilution in Milli-Q water for predetermined metal concentration. The $\mathrm{pH}$ of suspensions was adjusted by appropriate amount of $\mathrm{HCl}$ and $\mathrm{NaOH}$ with concentrations of 0.1 and $1 \mathrm{M}$. A known weight of adsorbent $(5 \mathrm{~g} / \mathrm{L})$ was added to a series of $100 \mathrm{~mL}$ Erlenmeyer flasks containing $40 \mathrm{~mL}$ of metal solution on a shaker (Ratek, Australia) at room temperature and $150 \mathrm{rpm}$ for $3 \mathrm{~h}$. After equilibration, to separate the biomasses from solutions, the solutions were filtered and final concentration of metal was measured using AAS

\subsection{Desorption studies in batch system}

Desorption of metal-loaded biosorbent was studied with four types of eluting agents including $0.1 \mathrm{M} \mathrm{NaCl}, 0.1 \mathrm{M} \mathrm{CaCl}_{2}, 0.1 \mathrm{M}$ $\mathrm{CH}_{3} \mathrm{COOH}$ and milli-Q water. This salts and organic acid were selected for eluting the use biosorbent due to prevent any damages to biosorbent structure. Following biosorption cycle with contact time of $3 \mathrm{~h}$, metal-loaded biosorbent was filtered and then added in $100 \mathrm{ml}$ of above solutions and shaken at $150 \mathrm{rpm}$ for $3 \mathrm{~h}$. After desorption, adsorbent was washed repeatedly with milli-Q water to remove any residual eluting solution and used for the next biosorption cycle.

\subsection{Calculations}

The amount of heavy metal ion adsorbed, $\mathrm{q}(\mathrm{mg} / \mathrm{g})$ was calculated from the following Eq. (1):

$Q=\frac{v\left(C_{i}-C_{f}\right)}{m}$

where, $C_{f}$ and $C_{i}(\mathrm{mg} / \mathrm{L})$ are the initial and equilibrium metal concentrations in the solution, respectively. $v(\mathrm{~L})$ the solution volume and $m(\mathrm{~g})$ is the mass of biosorbent. All the experiments were carried out in duplicates and the deviation within $5 \%$

\section{Results and discussion}

\subsection{Selection of adsorbents}

Six individual biosorbents, namely, sawdust (SD), sugarcane (SC), corncob (CC) and tea waste (TW), apple peel (AP) and also grape stalk (GS), individually (biosorbent dose: $5 \mathrm{~g} / \mathrm{L}, 50 \mathrm{ppm}$ initial metal Conc. at room temperature and $\mathrm{pH}$ of $5.0-5.5$, rotary speed of $150 \mathrm{rpm}$ for $24 \mathrm{~h}$ ) were evaluated and compared in terms of biosorption capacity (Fig. 1). As can be seen in Fig. 1, TW showed the best in removing all tested heavy metal ions (cadmium, copper, lead and zinc) while SC, SD and CC had quite less biosorptive capacity in comparison with GS and TW. AP for $\mathrm{Pb}, \mathrm{Zn}, \mathrm{Cd}$ and $\mathrm{Cu}$ removals was very dissatisfactory. Among four MMBBs with different combinations, MMBB2 had highest adsorption capacity of $\mathrm{Pb}, \mathrm{Cu}$ and $\mathrm{Zn}(8.08$ and $5.49 \mathrm{mg} / \mathrm{g}$, $1.66 \mathrm{mg} / \mathrm{g}$, respectively). However, MMBB2 was not as good as MMBB1 and MMBB3 in terms of Cd removal. Overall, MMBB2 (TW-CC-SD combination) with ratio of $1: 1: 1$ was selected to apply for further experiments. The $\mathrm{pH}$, moisture content (\%), loss of mass and bulk density $\mathrm{g} / \mathrm{cm}^{3}$ ) of MMBB2 were $5.16,18.63,0.92$ and 0.23 , respectively.

\subsection{Characterization of adsorbents by FTIR}

To determine the functional groups involved in biosorption of $\mathrm{Cd}(\mathrm{II}), \mathrm{Cu}(\mathrm{II}), \mathrm{Pb}(\mathrm{II})$ and $\mathrm{Zn}(\mathrm{II})$ onto MMBB2, a comparison between the FTIR spectra before and after meal loading was done using SHIMADZU FTIR 8400S (Kyoto, Japan). The FTIR spectrum of MMBB2 exhibited a large number of absorption peaks, indicating the complexity in nature of this adsorbent. It also confirmed changes in functional groups and surface properties of MMBB2. The shift of some functional groups bands and their intensity changed because of heavy metal biosorption (Table 1 ). These shifts may be attributed to carboxylic $(\mathrm{C}=\mathrm{O})$ and hydroxylic $(\mathrm{O}-\mathrm{H})$ groups on the MMBB2's surface. They were dominantly active groups in $\mathrm{Cd}(\mathrm{II})$, $\mathrm{Cu}(\mathrm{II}), \mathrm{Pb}(\mathrm{II})$ and $\mathrm{Zn}(\mathrm{II})$ biosorption process, suggesting that acidic groups, carboxyl and hydroxyl, are main contributors in the complexation of metal cations and ion exchange processes. Amine and amide groups were found between medium intensity peaks in the frequency range of 3400-3250 with $4.9 \mathrm{~cm}^{-1}$ shift after biosorption process. The strong peaks detected in spectra were lied between $1320-1000$ and $1820-1680 \mathrm{~cm}^{-1}$ which are related to $\mathrm{C}-\mathrm{O}$ stretch $(\mathrm{COOH})$ and $\mathrm{C}=\mathrm{O}$ stretch in amides, ketones, aldehydes, carboxylic acids and esters, respectively (Feng et al., 2011; Hossain et al., 2012). 


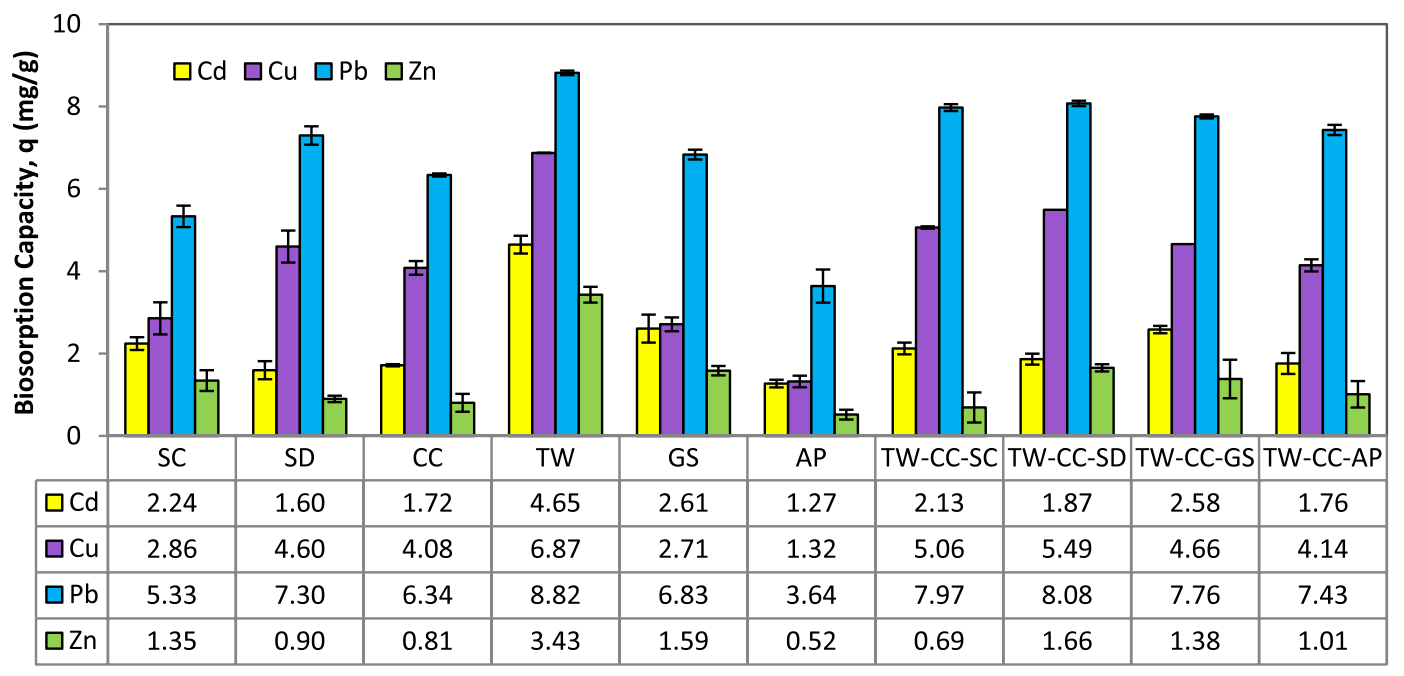

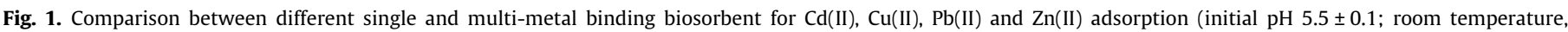

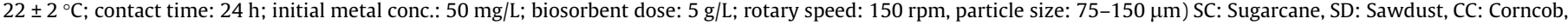
TW: Tea Waste, GS: Grape Stalk and AP: Apple Peels.

Table 1

FTIR spectra of unloaded and metal loaded-biosorbents.

\begin{tabular}{|c|c|c|c|c|c|}
\hline \multicolumn{2}{|c|}{ Wavelength range $\left(\mathrm{cm}^{-1}\right)$} & \multicolumn{3}{|c|}{ Transmittance (\%) } & \multirow[t]{2}{*}{ Bond/functional group } \\
\hline Frequency & Difference & Unloaded & Loaded & Difference & \\
\hline $3500-3200$ & -8.3 & 71.8 & 64.4 & -7.4 & $\mathrm{O}-\mathrm{H}$ stretch/alcohols and phenols \\
\hline $3400-3250$ & -4.9 & 64.5 & 53.5 & -11.0 & $\mathrm{~N}-\mathrm{H}$ band $/ 1^{\circ}$ and $2^{\circ}$ amines and amides \\
\hline $3000-2850$ & -10.4 & 73.2 & 65.7 & -7.5 & $\mathrm{H}-\mathrm{C}-\mathrm{H}$ asymmetric and symmetric stretch/alkanes \\
\hline $1820-1680$ & -9.1 & 69.3 & 64.3 & -5.0 & $\mathrm{C}=\mathrm{O}$ stretch/amides, ketones, aldehydes, carboxylic acids and esters \\
\hline $1470-1450$ & -3.6 & 62.7 & 61.1 & -1.7 & $\mathrm{C}-\mathrm{H}$ band/alkanes \\
\hline $1550-1475$ & +6.0 & 72.3 & 65.5 & -6.8 & $\mathrm{~N}-\mathrm{O}$ asymmetric stretch/nitro compounds \\
\hline $1320-1000$ & -9.3 & 79.1 & 68.5 & -10.6 & C-O stretch $(\mathrm{COOH}) /$ alcohol, carboxylic acid, esters and ethers \\
\hline
\end{tabular}

Moreover, a big change occurred on the biosorbent after metal loading which is reflected in the strong and broad band present between $3500-3200 \mathrm{~cm}^{-1}$. This may be assigned to complexation of metal ions with the ionized $\mathrm{O}-\mathrm{H}$ groups of polymeric compounds such as alcohols, phenols and carboxylic acids of cellulose and lignin of lignocellulosic materials (Feng et al., 2011; Hossain et al., 2012).

The changes of peaks in the range of 3000-2850 and $1470-1450 \mathrm{~cm}^{-1}$ indicated the involvement of $\mathrm{H}-\mathrm{C}-\mathrm{H}$ asymmetric and symmetric stretch and $\mathrm{C}-\mathrm{H}$ stretch of alkanes, respectively which can be found in the molecular structure of MMBB2.

\subsection{Effect of different physico-chemical parameters}

\subsubsection{Influence of $p H$}

The adsorption of cadmium, copper, lead and zinc was studied as a function of $\mathrm{pH}$ altering in the range of $2.0-5.5 \pm 0.1$. At initial $\mathrm{pH}$ values of 6.0, lead and copper hydroxide precipitation occurred. Thus, the experiments were not conducted beyond $\mathrm{pH} 5.5$ to avoid any precipitation. Fig. 2 shows that the adsorption capacity of metals increased with increasing in $\mathrm{pH}$ values in all cases. However, the changes of $\mathrm{Cu}$ and $\mathrm{Pb}$ adsorption was much more obvious than that of $\mathrm{Zn}$ and $\mathrm{Cd}$ (e.g., $\mathrm{Cu} ; 1.07-5.70 \mathrm{mg} / \mathrm{g}, \mathrm{Pb}: 2.50-8.53 \mathrm{mg} / \mathrm{g}, \mathrm{Zn}$ : $0.29-1.83 \mathrm{mg} / \mathrm{g}$ and $\mathrm{Cd}: 1.30-1.72 \mathrm{mg} / \mathrm{g}$ ). In addition some metal ions have better affinity towards biosorbents than other ions and this fact ascertains the selectivity potential of functional group (Šćiban et al., 2007). This phenomenon can be confirmed later by calculating the Langmuir parameter of $b_{L}$ representing this attraction.

\subsubsection{Influence of contact time}

A series of contact time experiments for cadmium, copper, lead and zinc adsorption on MMBB2 from 0 to $24 \mathrm{~h}$ were carried out at $50 \mathrm{mg} / \mathrm{L}$ initial concentration and room temperature. It is evident from the Fig. 3 that the rate of metal uptake was very fast within first 30 min as a result of exuberant number of available active sites on adsorbent surface and the process reached the equilibrium state within approximately $180 \mathrm{~min}$ of contact time for all cases.

\subsubsection{Influence of adsorbent dose}

As shown in Fig. 4, there is a hike in removal efficiency of all heavy metal ions on MMBB2 when adsorbent dose increased and after $5 \mathrm{~g} / \mathrm{L}$ of adsorbent dose. As it plateaued, the optimum amount of adsorbent for future study would be $5 \mathrm{~g} / \mathrm{L}$ whose highest removal efficiencies were about $68 \%, 75 \%, 85 \%$ and $55 \%$ for $\mathrm{Cd}, \mathrm{Cu}$, $\mathrm{Pb}$ and $\mathrm{Zn}$, respectively.

\subsubsection{Sorption and desorption experiments}

The ability of biosorbent regeneration and batch sorption and desorption studies were conducted using four eluting agents $\left(0.1 \mathrm{M} \mathrm{NaCl}, 0.1 \mathrm{M} \mathrm{CaCl}_{2}, 0.1 \mathrm{M} \mathrm{CH}_{3} \mathrm{COOH}\right.$ and Milli-Q water). The biosorption capacity of eluted biosorbent was tested in five repeated cycles at optimum $\mathrm{pH} 5.5 \pm 0.1$ and $50 \mathrm{mg} / \mathrm{L}$ initial metal concentrations. The contact time was $3 \mathrm{~h}$ for sorption and desorption in each cycle. The biosorption capacity of MMBB2 for Cd(II), $\mathrm{Cu}(\mathrm{II}), \mathrm{Pb}(\mathrm{II})$ and $\mathrm{Zn}(\mathrm{II})$ removal in the five cycles are indicated in Fig. 5. To evaluate level of significance in the sorption and desorption cycles on the biosorption capacity, SPSS software was used for statistical testing of the model in the form of analysis of variance 


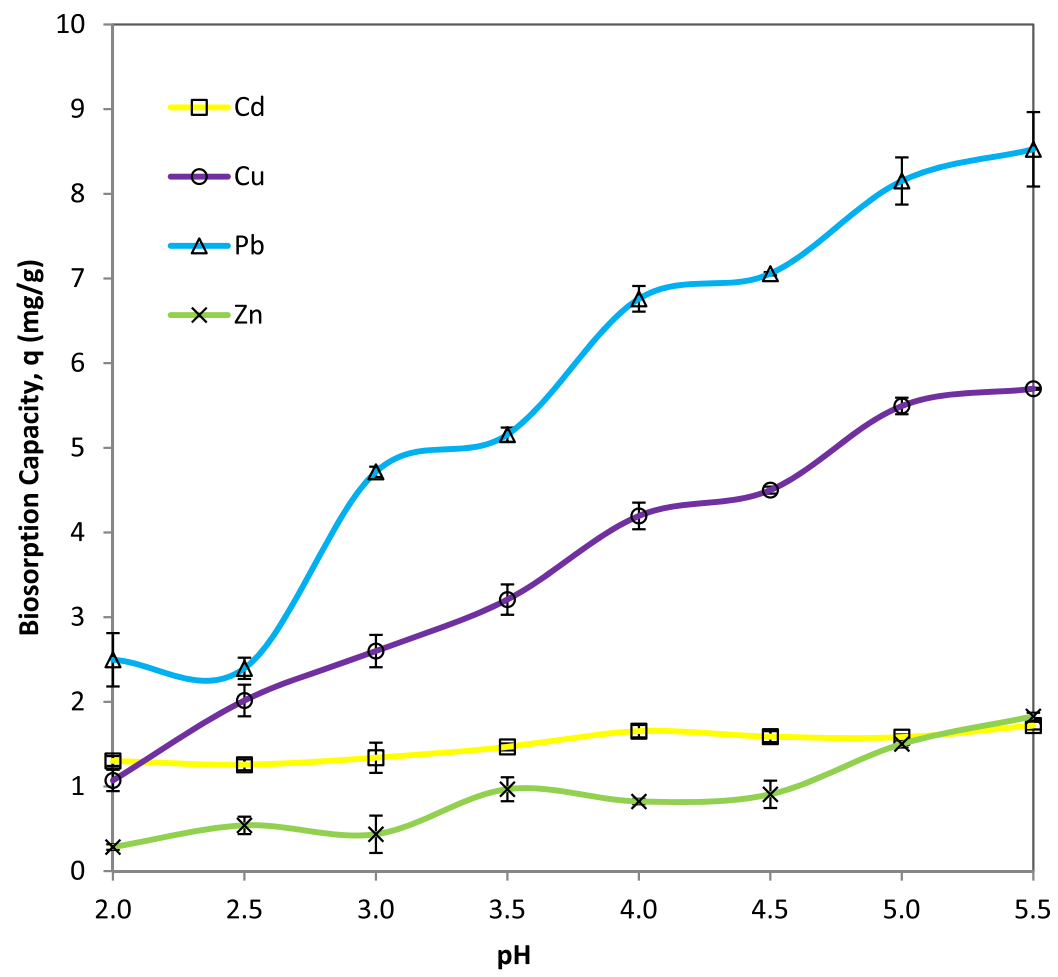

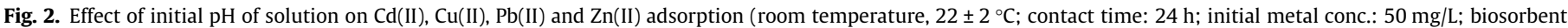
dose: $5 \mathrm{~g} / \mathrm{L}$; rotary speed: $150 \mathrm{rpm}$, particle size: $75-150 \mu \mathrm{m})$.

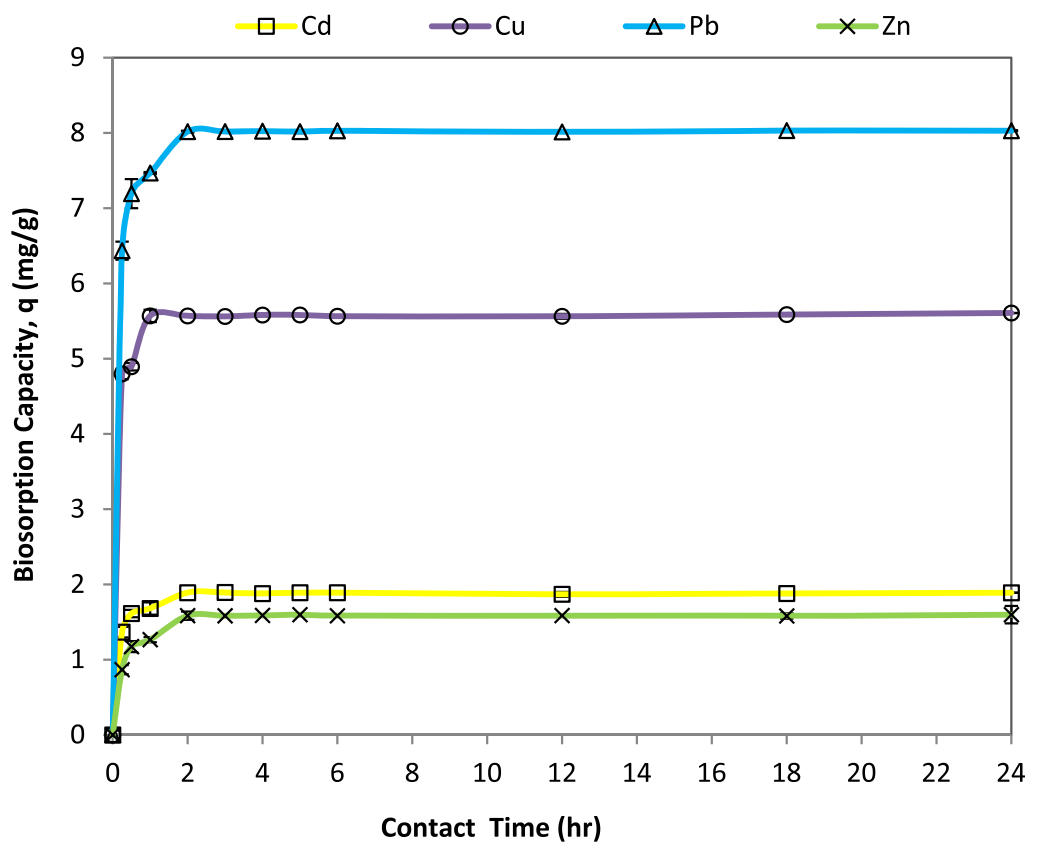

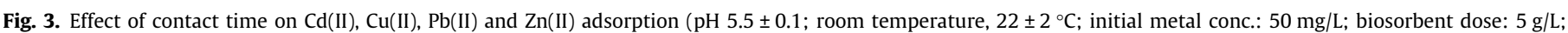
rotary speed: $150 \mathrm{rpm}$, particle size: $75-150 \mu \mathrm{m})$.

(ANOVA) and the one-sample $t$-test were done. For a $5 \%$ level of significance, the ANOVA data are given in Table 2. From this table for all metals, $P$ value is less than 0.05 and also the values of $F$ are higher than the critical $F$. Therefore, the type of eluent affects the sorption capacity and there is significant difference between the four desorbing agents in $\mathrm{Cd}(\mathrm{II}), \mathrm{Cu}(\mathrm{II}), \mathrm{Pb}(\mathrm{II})$ and $\mathrm{Zn}(\mathrm{II})$ removal.
In this case, a $P$ value less than 0.05 would result in the rejection of the null hypothesis at the 5\% (significance) level.

For a $5 \%$ level of significance $T$ values for $\mathrm{NaCl}, \mathrm{CH}_{3} \mathrm{COOH}$ and $\mathrm{CaCl}_{2}$, for all $\mathrm{Zn}(\mathrm{II})$ and $\mathrm{Cd}(\mathrm{II})$, the $P$ value is higher than 0.05 and also the values of $T$ are lower than the critical $T$ (2.13). In other word, it is obvious from the $t$-tests that for these eluents, the num- 


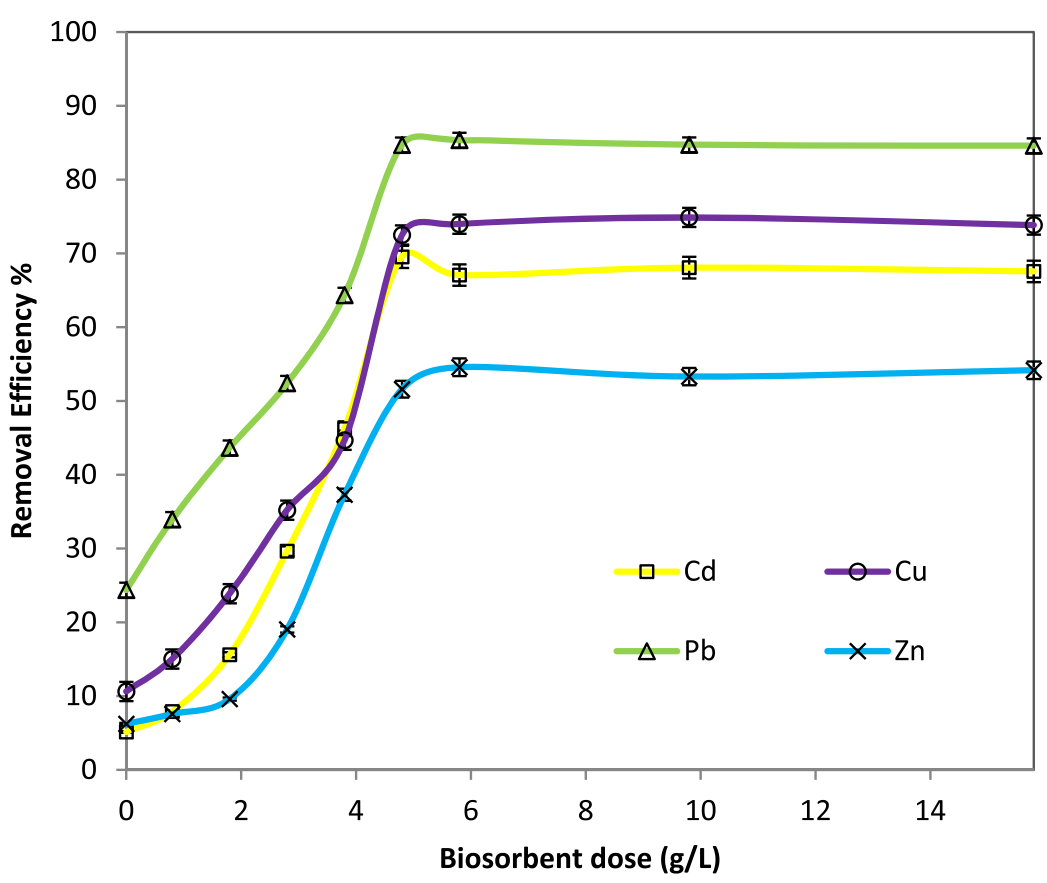

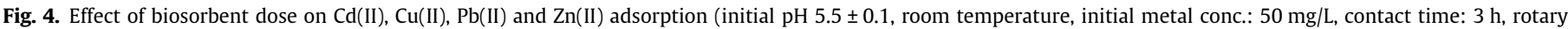
speed: $150 \mathrm{rpm}$, particle size: $75-150 \mu \mathrm{m})$.

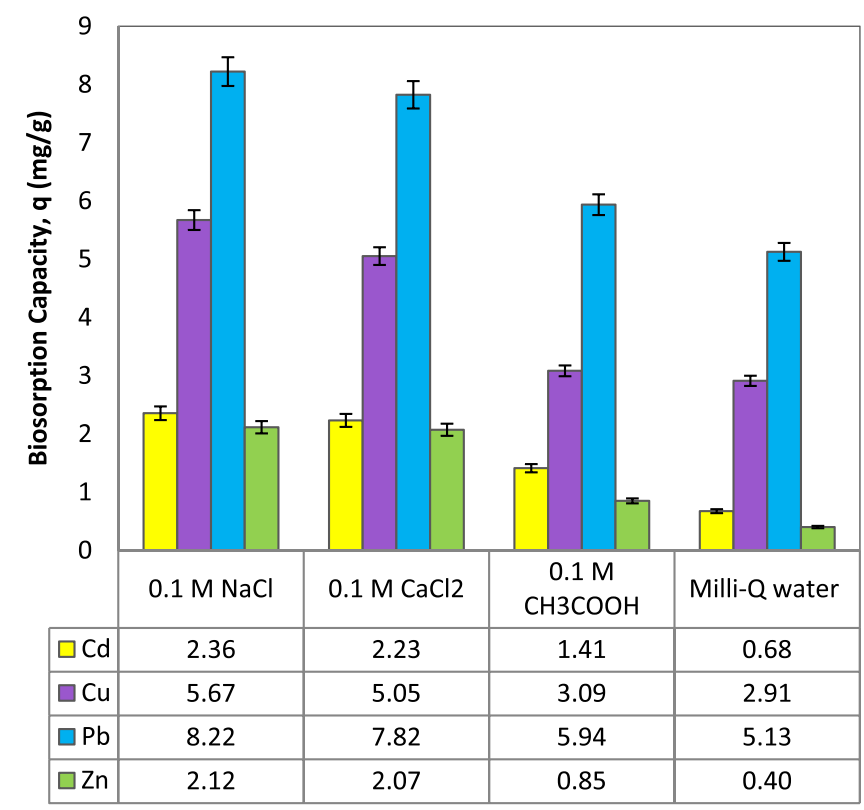

Fig. 5. Biosorption capacity of $\mathrm{Cd}(\mathrm{II}), \mathrm{Cu}(\mathrm{II}), \mathrm{Pb}(\mathrm{II})$ and $\mathrm{Zn}(\mathrm{II})$ onto $\mathrm{MMBB} 2$ washed by four eluting agents (optimum $\mathrm{pH} 5.5 \pm 0.1$; room temperature: $22 \pm 2{ }^{\circ} \mathrm{C}$; sorption time: $3 \mathrm{~h}$; desorption time: $3 \mathrm{~h}$; 5 cycles; initial metal conc.: $50 \mathrm{mg} / \mathrm{L}$ ).

ber of elution times does not affect the biosorption process. However, biosorption results show that the effect of $\mathrm{CaCl}_{2}$ and $\mathrm{NaCl}$ on the biosorbent is significant and causes higher increase in the sorption capacity in comparison with $\mathrm{CH}_{3} \mathrm{COOH}$ and Milli-Q water. Hence, these two chemicals are recommended as elution agents and desorption of cadmium, copper, lead and zinc from the biosorbent. Of course the much lower cost of $\mathrm{NaCl}$ should also be taken into consideration.
Table 2

ANOVA and One sample $t$-test data for sorption and desorption experiments of $\mathrm{Cd}(\mathrm{II})$ $\mathrm{Cu}(\mathrm{II}), \mathrm{Pb}(\mathrm{II})$ and $\mathrm{Zn}(\mathrm{II})$ biosorption onto MMBB2 (optimum $\mathrm{pH} 5.5 \pm 0.1$; room temperature: $22 \pm 2{ }^{\circ} \mathrm{C}$; sorption time: $3 \mathrm{~h}$; desorption time: $3 \mathrm{~h}$; 5 cycles; initial metal conc.: $50 \mathrm{mg} / \mathrm{L}$ ).

\begin{tabular}{|c|c|c|c|c|}
\hline \multirow[t]{2}{*}{ Statistical analysis method } & \multicolumn{4}{|l|}{ Metal } \\
\hline & $\mathrm{Cd}$ & $\mathrm{Cu}$ & $\mathrm{Pb}$ & $\mathrm{Zn}$ \\
\hline \multicolumn{5}{|c|}{ One-way ANOVA for $\mathrm{NaCl}, \mathrm{CaCl}_{2}, \mathrm{CH}_{3} \mathrm{COOH}$ and Milli-Q water } \\
\hline F factor & 12.23 & 4.66 & 4.86 & 4.59 \\
\hline $\mathrm{F}_{\text {critical }}$ factor & 3.23 & 3.23 & 3.23 & 3.23 \\
\hline$P$ value & 0.0002 & 0.0158 & 0.0136 & 0.0166 \\
\hline \multicolumn{5}{|l|}{ One-sample $\mathrm{T}$ for $\mathrm{NaCl}$} \\
\hline$T$ factor & 2.31 & 4.08 & 4.66 & 0.02 \\
\hline$T_{\text {critical }}$ factor & 2.13 & 2.13 & 2.13 & 2.13 \\
\hline$P$ & 0.04 & 0.007 & 0.004 & 0.49 \\
\hline \multicolumn{5}{|l|}{ One-sample $\mathrm{T}$ for $\mathrm{CaCl}_{2}$} \\
\hline$T$ factor & 0.64 & 4.92 & 4.47 & 1.19 \\
\hline$T_{\text {critical }}$ factor & 2.13 & 2.13 & 2.13 & 2.13 \\
\hline$P$ & 0.27 & 0.004 & 0.005 & 0.15 \\
\hline \multicolumn{5}{|l|}{ One-sample $\mathrm{T}$ for $\mathrm{CH}_{3} \mathrm{COOH}$} \\
\hline T factor & 1.93 & 7.16 & 5.19 & 2.81 \\
\hline $\mathrm{T}_{\text {critical }}$ factor & 2.13 & 2.13 & 2.13 & 2.13 \\
\hline P & 0.06 & 0.001 & 0.003 & 0.02 \\
\hline \multicolumn{5}{|l|}{ One-sample $T$ for Milli-Q water } \\
\hline$T$ factor & 5.00 & 5.60 & 4.76 & 5.48 \\
\hline$T_{\text {critical }}$ factor & 2.13 & 2.13 & 2.13 & 2.13 \\
\hline$P$ & 0.003 & 0.02 & 0.004 & 0.005 \\
\hline
\end{tabular}

\subsection{SEM analysis}

Scanning Electron Microscopy (SEM) of the free and loaded biomass of TMM and MMBB2 was performed on ZEISS EVO|LS15 (Germany) at an accelerating voltage of $10 \mathrm{kV}$ and with the working distance of $10-100 \mu \mathrm{m}$ for MMBB2 to elucidate the porous properties of the biosorbents. SEM images exhibited the morphological changes on the biosorbent surface before and after metal biosorption as well as 5 cycle of sorption and desorption. The surface of natural MMBB2 was found to be more porous and rougher than 
that of metal-loaded biosorbent. It was also observed that after 5 cycles of sorption and desorption, the surface of MMBB2 remained as rough as that of biosorbent after only one sorption process.

\subsection{Adsorption kinetics}

In batch systems, the adsorption kinetics was described by a number of models with varying degrees of complexity such as pseudo-first-order, pseudo-second-order and intra-particle diffusion kinetic model. The pseudo-first-order kinetic model known as the Lagergren equation and takes the form as (Febrianto et al., 2009):

$q_{t}=q_{e}\left[1-\exp \left(-K_{1} t\right)\right]$

where, $q_{t}$ and $q_{e}$ are the metal adsorbed at time $t$ and equilibrium, respectively, and $K_{1}\left(\mathrm{~min}^{-1}\right)$ is the first-order reaction rate equilibrium constant.

The pseudo-second-order kinetic model considered in this study is as follows:

$\frac{t}{q_{t}}=\frac{1}{K_{2} q_{e}^{2}}+\frac{t}{q e}$

where, $K_{2}\left(\mathrm{~g} \mathrm{mg}^{-1} \mathrm{~min}^{-1}\right)$ is the second-order reaction rate equilibrium constant.

The intra-particle diffusion model follows:

$q_{t}=K_{p} t^{1 / 2}+C$

The experimental data and obtained parameters of these models were measured by MATLAB ${ }^{\circledR}$ and shown in Table 3 . The results indicate that pseudo-second-order kinetic model can describe experimental data better than the two other kinetic models $\left(R^{2}=0.99\right)$, suggesting that chemical reaction would be presumably the rate limiting step of $\mathrm{Cd}, \mathrm{Cu}, \mathrm{Pb}$ and $\mathrm{Zn}$ biosorption on MMBB2. The calculated value of $q_{e}$ for pseudo-second-order kinetic model (1.92, $5.88,8.06$ and $1.60 \mathrm{mg} / \mathrm{g}$ for $\mathrm{Cd}(\mathrm{II}), \mathrm{Cu}(\mathrm{II}), \mathrm{Pb}(\mathrm{II})$ and $\mathrm{Zn}(\mathrm{II})$, respectively) are also close to the experimental values (1.89, 5.57, 8.04 and $1.60 \mathrm{mg} / \mathrm{g}$ ).

\subsection{Adsorption isotherm}

To optimize the design of biosorption process, it is necessary to acquire the appropriate correlation for equilibrium curve. In this study, the metal biosorption capacity as a function of metal concentration $(1-500 \mathrm{mg} / \mathrm{g})$ at equilibrium state has been described by very common two-parameter models of Langmuir, Freundlich, Dubinin-Radushkevich and Temkin and three-parameter models of Sips, Redlich-Peterson and Radke-Prausnitz adsorption isotherms. All the model parameters were evaluated by non-linear regression using MATLAB $^{\circledR}$ software. Furthermore, residual root mean square error (RMSE), error sum of square (SSE) and coefficient of determination $\left(R^{2}\right)$ were used to measure the goodness of fitting along with model parameters.

Langmuir isotherm model is as follows:

$q_{e}=\frac{q_{m, L} b_{L} C_{e}}{1+b_{L} C_{e}}$

where, $q_{m, L}$ is the maximum metal biosorption and $b_{L}(\mathrm{~L} / \mathrm{mg})$ the Langmuir constant. These constants related to monolayer adsorption capacity and energy of adsorption, respectively (Tan et al., 2010). Maximum monolayer adsorption capacities $\left(q_{m, L}\right)$ were $41.48,39.48,94.00$ and $27.23 \mathrm{mg} / \mathrm{g}$ for $\mathrm{Cd}(\mathrm{II}), \mathrm{Cu}(\mathrm{II}), \mathrm{Pb}(\mathrm{II})$ and $\mathrm{Zn}(\mathrm{II})$ sorption, respectively. The $b$ values of $\mathrm{Cd}(\mathrm{II}), \mathrm{Cu}(\mathrm{II}), \mathrm{Pb}(\mathrm{II})$ and $\mathrm{Zn}(\mathrm{II})$ biosorption which were estimated from this isotherm are 0.001 , $0.004,0.007$ and $0.002 \mathrm{~L} / \mathrm{mg}$, respectively and shows the steepest initial isotherm slope (the highest $b_{L}$ ) is for $\mathrm{Pb}(\mathrm{II})$ as can be expected.

Freundlich isotherm model is an empirical equation presented as follows (Montazer-Rahmati et al., 2011):

$q_{e}=K_{F} C_{e}^{1 / n}$

where $K_{F}(\mathrm{~L} / \mathrm{g})$ is Freundlich constant and $\mathrm{n}$ the Freundlich exponent. It is assumed that the stronger binding sites on a heterogeneous surface are occupied first and binding strength decreases with increasing degree of site occupation.

From Table 4(a), it is apparent that equilibrium data of $\mathrm{Cd}(\mathrm{II})$, $\mathrm{Cu}(\mathrm{II})$ and $\mathrm{Pb}(\mathrm{II})$ biosorption fitted well by the Freundlich isotherm $\left(R^{2}=0.99\right)$ and for $\mathrm{Zn}(\mathrm{II})$ the Langmuir isotherm was quite better fitted than Freundlich isotherm according to the values of $R^{2}$ of Langmuir isotherm model (0.97) being higher than that of Freundlich isotherm (0.95) as well as values of RMSE and SSE which are quite less than those of the other three models. Besides, it was understood that the Langmuir isotherm corresponded to a dominant ion exchange mechanism while the Freundlich isotherm showed adsorption-complexation reactions taking place in the adsorption process (Asadi et al., 2008).

The Dubinin-Radushkevich (D-R) equation is generally expressed as follows:

$q_{e}=q_{\mathrm{D}-\mathrm{R}} \exp \left(-B_{\mathrm{D}-\mathrm{R}} \epsilon_{\mathrm{D}-\mathrm{R}}^{2}\right)$

$\epsilon_{\mathrm{D}-\mathrm{R}}=\mathrm{RT} \ln \left(1+\frac{1}{C_{e}}\right)$

Where $\varepsilon_{\mathrm{D}-\mathrm{R}}$, the Polanyi potential, is a constant related to the biosorption energy, $R$ is the gas constant $(8.314 \mathrm{~kJ} / \mathrm{mol})$ and $T$ is the absolute temperature $(K) . q_{\mathrm{D}-\mathrm{R}}$ and $B_{\mathrm{D}-\mathrm{R}}$ are the $\mathrm{D}-\mathrm{R}$ isotherm constants in $\mathrm{mg} / \mathrm{g}$ and $\mathrm{mol}^{2} / \mathrm{kJ}^{2}$, respectively. Moreover, the mean free energy of adsorption $\left(E=\frac{1}{\sqrt{2 B_{\mathrm{D}-\mathrm{R}}}}\right)$ calculated from Dubinin-

Table 3

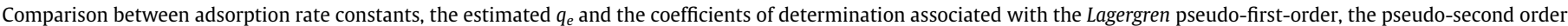

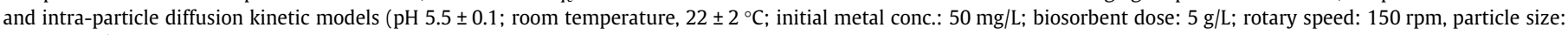
$75-150 \mu \mathrm{m})$.

\begin{tabular}{|c|c|c|c|c|c|}
\hline \multirow[t]{2}{*}{ Model } & \multirow[t]{2}{*}{ Parameter } & \multicolumn{4}{|c|}{ Metal } \\
\hline & & $\mathrm{Cd}$ & $\mathrm{Cu}$ & $\mathrm{Pb}$ & $\mathrm{Zn}$ \\
\hline Experimental & $q_{e, \exp }(\mathrm{mg} / \mathrm{g})$ & 1.89 & 5.57 & 8.04 & 1.60 \\
\hline \multirow[t]{3}{*}{ 1st-order kinetic model $\left.q_{t}=q_{e}\left[1-\exp \left(-K_{1} t\right)\right]\right]$} & $K_{1}\left(\min ^{-1}\right)$ & 0.03 & 0.10 & 0.07 & 0.02 \\
\hline & $q_{e, \mathrm{cal}}(\mathrm{mg} / \mathrm{g})$ & 1.19 & 5.98 & 8.39 & 1.21 \\
\hline & $R^{2}$ & 0.79 & 0.95 & 0.94 & 0.85 \\
\hline \multirow{3}{*}{ 2nd-order kinetic model $\frac{t}{q_{t}}=\frac{1}{K_{2} q_{e}^{2}}+\frac{t}{q_{e}}$} & $K_{2} \times 10^{3}\left(\mathrm{~g} \mathrm{mg}^{-1} \mathrm{~min}^{-1}\right)$ & 0.17 & 0.08 & 0.06 & 0.09 \\
\hline & $q_{e, \mathrm{cal}}(\mathrm{mg} / \mathrm{g})$ & 1.92 & 5.88 & 8.06 & 1.60 \\
\hline & $R^{2}$ & 0.99 & 0.99 & 0.99 & 0.99 \\
\hline \multirow[t]{3}{*}{ Intra-particle diffusion model $q_{t}=K_{P} t^{0.5}+C$} & $K_{P}\left(\mathrm{mg} \mathrm{g}^{-1} \min ^{-0.5}\right)$ & 0.07 & 1.12 & 0.15 & 0.07 \\
\hline & $C$ & 1.16 & 4.35 & 6.19 & 0.68 \\
\hline & $R^{2}$ & 0.93 & 0.81 & 0.88 & 0.90 \\
\hline
\end{tabular}


Table 4

Isotherm constants of (a) two-parameter and (b) three-parameter models for $\mathrm{Cd}(\mathrm{II}), \mathrm{Cu}(\mathrm{II}), \mathrm{Pb}$ (II) and $\mathrm{Zn}$ (II) adsorption (initial pH $5.5 \pm 0.1$, initial metal Conc.: $1-500 \mathrm{mg} / \mathrm{L}$, contact time: $3 \mathrm{~h}$, rotary speed: $150 \mathrm{rpm}$, biosorbent dose: $5 \mathrm{~g} / \mathrm{L}$, particle size: $75-$ $150 \mu \mathrm{m})$.

\begin{tabular}{|c|c|c|c|c|}
\hline & \multicolumn{4}{|l|}{ Metal } \\
\hline & Cadmium & Copper & Lead & Zinc \\
\hline \multicolumn{5}{|c|}{ (a) Two-parameter models } \\
\hline \multicolumn{5}{|c|}{ Langmuir $q_{e}=\frac{q_{m, L} b_{L} C_{e}}{1+b_{L} C_{e}}$} \\
\hline$q_{m, L}(\mathrm{mg} / \mathrm{g})$ & 41.48 & 39.48 & 94.00 & 27.23 \\
\hline$b_{L}(\mathrm{~L} / \mathrm{mg})$ & 0.001 & 0.004 & 0.007 & 0.002 \\
\hline SSE & 2.24 & 4.52 & 65.03 & 3.89 \\
\hline$R^{2}$ & 0.99 & 0.99 & 0.97 & 0.97 \\
\hline RMSE & 0.75 & 1.06 & 4.03 & 0.98 \\
\hline \multicolumn{5}{|c|}{ Freundlich $q_{e}=K_{F} C_{e}^{1 / n}$} \\
\hline$K_{F}$ & 0.21 & 0.63 & 2.57 & 0.18 \\
\hline$n$ & 1.37 & 1.63 & 1.74 & 1.42 \\
\hline SSE & 1.83 & 0.27 & 12.71 & 6.65 \\
\hline$R^{2}$ & 0.99 & 0.99 & 0.99 & 0.95 \\
\hline RMSE & 0.67 & 0.25 & 1.78 & 1.29 \\
\hline \multicolumn{5}{|c|}{ Dubinin-Radushkevich $q_{e}=q_{\mathrm{D}-\mathrm{R}} \exp \left(-B_{\mathrm{D}-\mathrm{R}} \epsilon_{D-R}^{2}\right)$} \\
\hline$q_{\mathrm{D}-\mathrm{R}}(\mathrm{mg} / \mathrm{g})$ & 18.00 & 21.68 & 47.99 & 14.56 \\
\hline$B_{\mathrm{D}-\mathrm{R}}$ & 0.008 & 0.005 & 0.004 & 0.018 \\
\hline SSE & 18.54 & 59.54 & 40.60 & 6.50 \\
\hline$R^{2}$ & 0.91 & 0.83 & 0.81 & 0.96 \\
\hline RMSE & 2.15 & 3.85 & 10.07 & 1.27 \\
\hline \multicolumn{5}{|c|}{ Temkin $q_{e}=\frac{R T}{b_{\mathrm{Te}}} \ln \left(K_{\mathrm{Te}} C_{e}\right)$} \\
\hline$K_{\mathrm{Te}}(\mathrm{L} / \mathrm{g})$ & 0.15 & 0.21 & 1.16 & 0.08 \\
\hline$b_{\mathrm{Te}}(\mathrm{kJ} / \mathrm{mol})$ & 0.77 & 0.55 & 0.31 & 0.77 \\
\hline SSE & 50.17 & 56.4 & 42.34 & 26.89 \\
\hline$R^{2}$ & 0.75 & 0.84 & 0.80 & 0.82 \\
\hline RMSE & 3.54 & 3.75 & 10.29 & 2.59 \\
\hline \multicolumn{5}{|c|}{ (b) Three-parameter models } \\
\hline \multicolumn{5}{|c|}{ Radke-Prausnitz $q_{e}=\frac{a_{\mathrm{R}-\mathrm{p}} r_{\mathrm{R}-\mathrm{p}} C_{e}^{\beta_{\mathrm{R}-\mathrm{p}}}}{a_{\mathrm{R}-\mathrm{p}}+r_{\mathrm{R}-\mathrm{p}} C_{e}^{\beta_{\mathrm{R}-\mathrm{p}-1}}}$} \\
\hline$a_{\mathrm{R}-\mathrm{P}}(\mathrm{L} / \mathrm{g})$ & 5.10 & 9.24 & 3.25 & 4.10 \\
\hline$\beta_{\mathrm{R}-\mathrm{P}}$ & 0.68 & 0.61 & 0.57 & 0.70 \\
\hline$r_{\mathrm{R}-\mathrm{P}}(\mathrm{L} / \mathrm{mg})$ & 0.21 & 0.63 & 2.57 & 0.18 \\
\hline SSE & 1.33 & 0.26 & 12.71 & 6.65 \\
\hline$R^{2}$ & 0.99 & 0.99 & 0.99 & 0.95 \\
\hline RMSE & 1.52 & 0.99 & 2.05 & 1.48 \\
\hline \multicolumn{5}{|c|}{ Redlich-Peterson $q_{e}=\frac{K_{\mathrm{RP}} C_{e}}{1+a_{\mathrm{RP}} C_{e}^{{ }_{\mathrm{RP}} \mathrm{P}}}$} \\
\hline$a_{\mathrm{RP}}(\mathrm{L} / \mathrm{mg})$ & 1.25 & 0.10 & 2.09 & 5.39 \\
\hline$\beta_{\mathrm{RP}}$ & 0.27 & 0.60 & 0.19 & 0.56 \\
\hline$K_{\mathrm{RP}}(\mathrm{L} / \mathrm{g})$ & 5.65 & 0.89 & 1.00 & 0.05 \\
\hline SSE & 1.83 & 6.77 & 0.23 & 2.87 \\
\hline$R^{2}$ & 0.99 & 0.99 & 0.99 & 0.98 \\
\hline RMSE & 0.78 & 4.75 & 0.27 & 0.97 \\
\hline \multicolumn{5}{|c|}{ Sips $q_{e}=\frac{K_{S} c_{e}^{\beta_{S}}}{1+a_{S} c^{\beta_{S}}}$} \\
\hline$a_{S}(\mathrm{~L} / \mathrm{mg})$ & 0.001 & 0.004 & 0.063 & 0.001 \\
\hline$\beta_{S}$ & 0.83 & 0.59 & 0.38 & 1.72 \\
\hline$K_{S}(\mathrm{~L} / \mathrm{g})$ & 0.20 & 0.66 & 3.68 & 0.002 \\
\hline SSE & 1.52 & 0.25 & 2.92 & 1.89 \\
\hline$R^{2}$ & 0.99 & 0.99 & 0.99 & 0.98 \\
\hline RMSE & 0.23 & 0.29 & 0.98 & 0.79 \\
\hline
\end{tabular}

Radushkevich isotherm which is applied to evaluate sorption properties and indicates if main mechanism is chemical reaction dominated by ion exchange or physical adsorption. Based on hypothesis of D-R isotherm, $E$ values between 8 and $12 \mathrm{~kJ} / \mathrm{mol}$ mean chemical adsorption by ion exchange process whereas $E$ values less than $8 \mathrm{~kJ} /$ mol means physical adsorption. Hence, according to calculated $B_{\mathrm{D}-\mathrm{R}}$ for $\mathrm{Cd}, \mathrm{Cu}, \mathrm{Pb}$ and $\mathrm{Zn}, \mathrm{E}$ values show physical adsorption for cadmium and zinc removal $(7.81$ and $5.27 \mathrm{~kJ} / \mathrm{mol}$, for $\mathrm{Cd}$ and $\mathrm{Zn}$, respectively) and ion-exchange process for lead and copper biosorption $(9.45 \mathrm{~kJ} / \mathrm{mol}$ for $\mathrm{Cu}$ and $10.54 \mathrm{~kJ} / \mathrm{mol}$ for $\mathrm{Pb})$.

According to Temkin isotherm, interactions between adsorbate and adsorbent make linear decrease in adsorption energy and heat of adsorption. The model is mathematically represented as (Febrianto et al., 2009):
$q_{e}=\frac{\mathrm{RT}}{b_{\mathrm{Te}}} \ln \left(K_{\mathrm{Te}} C_{e}\right)$

where $b_{\mathrm{Te}}(\mathrm{kJ} / \mathrm{mol})$ and $K_{\mathrm{Te}}(\mathrm{L} / \mathrm{g})$ are Temkin model constants which are $0.77,0.55,0.31$ and $0.77 \mathrm{~kJ} / \mathrm{mol}$ and $0.15,0.21,1.16$ and $0.08 \mathrm{~L} / \mathrm{g}$, for for $\mathrm{Cd}(\mathrm{II}), \mathrm{Cu}(\mathrm{II}), \mathrm{Pb}(\mathrm{II})$ and $\mathrm{Zn}(\mathrm{II})$, respectively. This model is not a proper correlation for examined heavy metals according to $R^{2}$, RMSE and SSE values.

Radke-Prausnitz isotherm can be represented as (MontazerRahmati et al., 2011):

$q_{e}=\frac{a_{\mathrm{R}-\mathrm{P}} r_{\mathrm{R}-\mathrm{P}} C_{e}^{\beta_{\mathrm{R}-\mathrm{P}}}}{a_{\mathrm{R}-\mathrm{P}}+r_{\mathrm{R}-\mathrm{P}} C_{e}^{\beta_{\mathrm{R}-\mathrm{P}-1}}}$ 
Table 5

Biosorption capacities of various biosorbent

\begin{tabular}{|c|c|c|c|}
\hline Adsorbent & Matal & $\begin{array}{l}q_{\max }(\mathrm{mg} / \\
\mathrm{g})\end{array}$ & References \\
\hline МMBВ2 & $\begin{array}{l}\mathrm{Cd}(\mathrm{II}) \\
\mathrm{Zn}(\mathrm{II}) \\
\mathrm{Pb}(\mathrm{II}) \\
\mathrm{Cu}(\mathrm{II})\end{array}$ & $\begin{array}{l}41.48 \\
27.23 \\
94.00 \\
39.48\end{array}$ & Present study \\
\hline $\begin{array}{r}\text { Sugarcane } \\
\text { bagasse }\end{array}$ & $\mathrm{Cd}(\mathrm{II})$ & 69.06 & Garg et al. (2008) \\
\hline Sawdust & $\begin{array}{l}\mathrm{Cu}(\mathrm{II}) \\
\mathrm{Zn}(\mathrm{II}) \\
\mathrm{Cd}(\mathrm{II})\end{array}$ & $\begin{array}{l}6.88 \\
0.96 \\
0.15\end{array}$ & Šćiban et al. (2007) \\
\hline $\begin{array}{l}\text { Rice straw } \\
\text { Olive stone }\end{array}$ & $\begin{array}{l}\mathrm{Cd}(\mathrm{II}) \\
\mathrm{Pb}(\mathrm{II}) \\
\mathrm{Cd}(\mathrm{II}) \\
\mathrm{Ni}(\mathrm{II}) \\
\mathrm{Cu}(\mathrm{II})\end{array}$ & $\begin{array}{l}13.89 \\
92.6 \\
77.3 \\
21.3 \\
20.2\end{array}$ & $\begin{array}{l}\text { Ding et al. (2012) } \\
\text { Fiol et al. (2006) }\end{array}$ \\
\hline Orange peel & $\begin{array}{l}\mathrm{Pb}(\mathrm{II}) \\
\mathrm{Cd}(\mathrm{II}) \\
\mathrm{Ni}(\mathrm{II})\end{array}$ & $\begin{array}{l}113.5 \\
63.35 \\
9.82\end{array}$ & \\
\hline $\begin{array}{l}\text { Cashew nut shell } \\
\text { Tea waste }\end{array}$ & $\begin{array}{l}\mathrm{Zn}(\mathrm{II}) \\
\mathrm{Cu}(\mathrm{II}) \\
\mathrm{Pb}(\mathrm{II})\end{array}$ & $\begin{array}{l}24.98 \\
48 \\
65\end{array}$ & $\begin{array}{l}\text { Kumar et al. (2012) } \\
\text { Amarasinghe and Williams } \\
\text { (2007) }\end{array}$ \\
\hline
\end{tabular}

where $a_{\mathrm{R}-\mathrm{P}}$ and $r_{\mathrm{R}-\mathrm{P}}$ are Radke-Prausnitz model constants and $\beta_{\mathrm{R}-\mathrm{P}}$ the Radke-Prausnitz model exponent. Radke-Prausnitz isotherm constants, $a_{\mathrm{R}-\mathrm{P}}$ and $r_{\mathrm{R}-\mathrm{P}}$ for $\mathrm{Cd}(\mathrm{II}), \mathrm{Cu}(\mathrm{II}), \mathrm{Pb}(\mathrm{II})$ and $\mathrm{Zn}$ (II) were calculated as $5.10,9.24,3.25$ and $4.10 \mathrm{~L} / \mathrm{mg}, 0.21,0.63,2.57$ and $0.18 \mathrm{~L} /$ $\mathrm{g}$, respectively.

As the results in Table 4(a), among two-parameter isotherms, both Freundlich and Langmuir models agreed very well with experimental data rather than the other two-parameter isotherm models and these are confirmed by small values of RMSE and SSE and $R^{2}$ amounts closed to 1.0 , too. This result indicates the formation of monolayer coverage of metal ions at the outer heterogeneous surface of the sorbent.

The Sips isotherm is a combination of the Langmuir and Freundlich isotherm models and is expected to describe heterogeneous surfaces much better. At high sorbate concentrations it predicts a monolayer adsorption capacity characteristic of the Langmuir isotherm whereas at low sorbate concentrations it reduces to the Freundlich isotherm. It is given as (Febrianto et al., 2009):

$q_{e}=\frac{K_{S} C_{e}^{\beta_{S}}}{1+a_{S} C_{e}^{\beta_{S}}}$

where $K_{S}$ and $a_{S}$ are the Sips model constants in $\mathrm{L} / \mathrm{g}$ and $\mathrm{L} / \mathrm{mg}$, respectively and $\beta_{S}$ is the Sips model exponent.

As the results given by Sips model (Table 4(b)), the experimental results of $\mathrm{Cd}(\mathrm{II}), \mathrm{Cu}(\mathrm{II})$ and $\mathrm{Zn}$ (II) biosorption are well fitted by all Sips better than Redlich-Peterson and Radke-Prausnitz models due to small RMSE and SSE as well as high $R^{2}$ close to 1.0.

Unlike Sips model, the Redlich-Peterson isotherm behaves like the Freundlich isotherm at high adsorbate concentrations and comes close the Henry's law at low amounts of concentration. The model can be presented as (Febrianto et al., 2009; MontazerRahmati et al., 2011):

$q_{e}=\frac{K_{\mathrm{RP}} C_{e}}{1+a_{\mathrm{RP}} C_{e}^{\beta_{\mathrm{RP}}}}$

where $K_{\mathrm{RP}}$ and $a_{\mathrm{RP}}$ are the Redlich-Peterson model constants in $\mathrm{L} / \mathrm{g}$ and $\mathrm{L} / \mathrm{mg}$, respectively and $\beta_{\mathrm{RP}}$ is the Redlich-Peterson model exponent which lies between 0 and $1(0.27,0.60,0.19$ and 0.56 for $\mathrm{Cd}(\mathrm{II})$, $\mathrm{Cu}(\mathrm{II}), \mathrm{Pb}(\mathrm{II})$ and $\mathrm{Zn}(\mathrm{II})$, respectively). $\mathrm{Pb}(\mathrm{II})$ biosorption data is best correlated by the Redlich-Peterson as confirmed by the smallest values of RMSE, SSE and $R^{2}$ values very close to 1.0 (0.999).

The foregoing analysis of isotherm models show that the best fit for $\mathrm{Cd}(\mathrm{II}), \mathrm{Cu}(\mathrm{II}), \mathrm{Pb}(\mathrm{II})$ and $\mathrm{Zn}(\mathrm{II})$ biosorption is produced by threeparameter isotherm models than two-parameter isotherm models.

Comparison between maximum adsorptive capacities of some adsorbents investigated by other researchers is shown in Table 5. This study results are compatible with other adsorbents by higher or at least equal sorptive potential for heavy metal removal from aqueous solutions. Besides, combination of several types of lowcost agro-industrial waste provides more selectivity as a result of increase in different effective functional groups involved in metal binding. Hence, this kind of adsorbent will be recommended for its significant advantages.

\section{Conclusion}

The new biosorbent containing tea waste, corncob and sawdust was found to be an effective and low-cost alternative for detoxifying of heavy metals contaminated aqueous solutions. The $\mathrm{pH}$, contact time, adsorbent dose and initial metal concentrations of the adsorbate significantly governed the overall process of cadmium, copper, lead and zinc cations adsorption. The sorption equilibrium time was reached within $3 \mathrm{~h}$ and pseudo-second-order kinetic model well fitted the experimental data. $\mathrm{NaCl}$ was successfully used as eluent without affecting its sorption capability after five cycles of sorption and desorption.

\section{Acknowledgement}

This work was supported by Centre for Technology in Water and Wastewater (CTWW), School of Civil and Environmental Engineering, University of Technology, Sydney (UTS) and Australian Postgraduate Award (APA).

\section{Appendix A. Supplementary data}

Supplementary data associated with this article can be found, in the online version, at http://dx.doi.org/10.1016/j.biortech.2013.12. 038.

\section{References}

Amarasinghe, B.M.W.P.K., Williams, R.A., 2007. Tea waste as a low cost adsorbent for the removal of $\mathrm{Cu}$ and $\mathrm{Pb}$ from wastewater. Chem. Eng. J. 132, 299-309.

Asadi, F., Shariatmadari, H., Mirghaffari, N., 2008. Modification of rice hull and sawdust sorptive characteristics for remove heavy metals from synthetic solutions and wastewater. J. Hazard. Mater. 154, 451-458.

Bilal, M., Shah, J.A., Ashfaq, T., Gardazi, S.M.H., Tahir, A.A., Pervez, A., Haroon, H., Mahmood, Q., 2013. Waste biomass adsorbents for copper removal from industrial wastewater - a review. J. Hazard. Mater. 263, 322-333.

Blázquez, G., Hernáinz, F., Calero, M., Martín-Lara, M.A., Tenorio, G., 2009. The effect of $\mathrm{pH}$ on the biosorption of $\mathrm{Cr}(\mathrm{III})$ and $\mathrm{Cr}(\mathrm{VI})$ with olive stone. Chem. Eng. J. $148,473-479$.

Bulut, Y., Tez, Z., 2007. Removal of heavy metals from aqueous solution by sawdust adsorption. J. Environ. Sci. 19, 160-166.

Ding, Y., Jing, D., Gong, H., Zhou, L., Yang, X., 2012. Biosorption of aquatic cadmium(II) by unmodified rice straw. Bioresour. Technol. 114, 20-25.

Febrianto, J., Kosasih, A.N., Sunarso, J., Ju, Y.-H., Indraswati, N., Ismadji, S., 2009. Equilibrium and kinetic studies in adsorption of heavy metals using biosorbent: a summary of recent studies. J. Hazard. Mater. 162, 616-645.

Feng, N., Guo, X., Liang, S., Zhu, Y., Liu, J., 2011. Biosorption of heavy metals from aqueous solutions by chemically modified orange peel. J. Hazard. Mater. 185, $49-54$.

Fiol, N., Villaescusa, I., Martínez, M., Miralles, N., Poch, J., Serarols, J., 2006. Sorption of $\mathrm{Pb}(\mathrm{II}), \mathrm{Ni}(\mathrm{II}), \mathrm{Cu}(\mathrm{II})$ and $\mathrm{Cd}(\mathrm{II})$ from aqueous solution by olive stone waste. Sep. Purif. Technol. 50, 132-140.

Gadd, G.M., 2009a. Heavy metal pollutants: environmental and biotechnological aspects. In: Schaechter, M. (Ed.), Encyclopedia of Microbiology, 3rd ed. Elsevier, Oxford, pp. 321-334. 
Gadd, G.M., 2009b. Biosorption: critical review of scientific rationale, environmental importance and significance for pollution treatment. J. Chem. Technol. Biotechnol. 84 (1), 13-28.

Garg, U., Kaur, M.P., Jawa, G.K., Sud, D., Garg, V.K., 2008. Removal of cadmium (II) from aqueous solutions by adsorption on agricultural waste biomass. J. Hazard. Mater. 154, 1149-1157.

Gupta, V.K., Carrott, P.J.M., Carrott, M.M.L.R., Suhas., 2009. Low-Cost adsorbents: growing approach to wastewater treatment-a review. Crit. Rev. Environ. Sci. Technol. 39, 783-842.

Homagai, P.L., Ghimire, K.N., Inoue, K., 2010. Adsorption behavior of heavy metals onto chemically modified sugarcane bagasse. Bioresour. Technol. 101, 20672069.

Hossain, M.A., Ngo, H.H., Guo, W.S., Setiadi, T., 2012. Adsorption and desorption of copper(II) ions onto garden grass. Bioresour. Technol. 121, 386-395.

Kazemipour, M., Ansari, M., Tajrobehkar, S., Majdzadeh, M., Kermani, H.R., 2008. Removal of lead, cadmium, zinc, and copper from industrial wastewater by carbon developed from walnut, hazelnut, almond, pistachio shell, and apricot stone. J. Hazard. Mater. 150, 322-327.

Kumar, P. S., Ramalingam, S., Abhinaya, R.V Kirupha, S.D. Vidhyadevi, T. Sivanesan, S., 2012. Adsorption equilibrium, thermodynamics, kinetics, mechanism and process design of zinc (II) ions onto cashew nut shell. Can. J. Chem. Eng. 90, 973-982.

Liu, C., Ngo, H.H., Guo, W., Tung, K.-L., 2012. Optimal conditions for preparation of banana peels, sugarcane bagasse and watermelon rind in removing copper from water. Bioresour. Technol. 119, 349-354.

Loukidou, M.X Zouboulis, A. I., Karapantsios, T. D, Matis, K. A 2004. Equilibrium and kinetic modeling of chromium(VI) biosorption by Aeromonas caviae. Colloids Surf. Physicochem. Eng. Aspects 242, 93-104.

Martín-Lara, M.Á., Rico, I.L.R., Vicente, I.d.l.C.A., García, G.B., de Hoces, M.C., 2010 Modification of the sorptive characteristics of sugarcane bagasse for removing lead from aqueous solutions. Desalination 256, 58-63.
Martín-Lara, M.A., Blázquez, G., Ronda, A., Rodríguez, I.L., Calero, M., 2012. Multiple biosorption-desorption cycles in a fixed-bed column for $\mathrm{Pb}$ (II) removal by acidtreated olive stone. J. Ind. Eng. Chem. 18, 1006-1012.

Montazer-Rahmati, M.M., Rabbani, P., Abdolali, A., Keshtkar, A.R., 2011. Kinetics and equilibrium studies on biosorption of cadmium, lead, and nickel ions from aqueous solutions by intact and chemically modified brown algae. J. Hazard. Mater. 185, 401-407.

Pehlivan, E., Altun, T., Parlayici, S., 2012. Modified barley straw as a potential biosorbent for removal of copper ions from aqueous solution. Food Chem. 135, 2229-2234.

Pereira, F.V., Gurgel, L.V.A., Gil, L.F., 2010. Removal of $\mathrm{Zn}^{2+}$ from aqueous single metal solutions and electroplating wastewater with wood sawdust and sugarcane bagasse modified with EDTA dianhydride (EDTAD). J. Hazard. Mater. 176, 856-863.

Šćiban, M., Radetić, B., Kevrešan, Ž., Klašnja, M., 2007. Adsorption of heavy metals from electroplating wastewater by wood sawdust. Bioresour. Technol. 98, 402409.

Tan, G., Xiao, D., 2009. Adsorption of cadmium ion from aqueous solution by ground wheat stems. J. Hazard. Mater. 164, 1359-1363.

Tan, G., Yuan, H., Liu, Y., Xiao, D., 2010. Removal of lead from aqueous solution with native and chemically modified corncobs. J. Hazard. Mater. 174, 740-745.

Torab-Mostaedi, M., Asadollahzadeh, M., Hemmati, A., Khosravi, A., 2013. Equilibrium, kinetic, and thermodynamic studies for biosorption of cadmium and nickel on grapefruit peel. J. Taiwan Inst. Chem. E 44, 295302.

Velazquez-Jimenez, L.H., Pavlick, A., Rangel-Mendez, J.R., 2013. Chemical characterization of raw and treated agave bagasse and its potential as adsorbent of metal cations from water. Ind. Crop. Prod. 43, $200-$ 206.

Volesky, B., 2007. Biosorption and me. Water Res. 41, 4017-4029. 